\title{
Eemian to Early Weichselian organic deposits in the watershed kettle-hole basins in central Poland
}

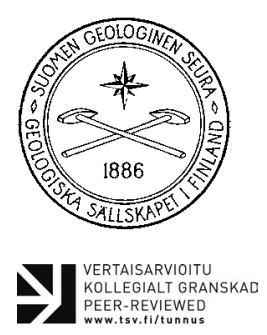
KOLLEGIALT GRAN
PEER-REVIEWED
www.tsv.fi/tunnus

\author{
Jacek Forysiak ${ }^{I^{*}}$, Aleksandra Majecka², LeszeK Marks ${ }^{2}$ \\ AND DANIEL OKUPNY3
}

${ }^{1}$ Department of Geomorfology and Paleogeography, Institute of Earth Sciences, University of Łódż, Narutowicza 88, 90-139 Eódż, POLAND

${ }^{2}$ Faculty of Geology, University of Warsaw, Al. Żwirki i Wigury 93, 02-098 Warszawa, POLAND

${ }^{3}$ Institute of Geography, Pedagogical University of Kraków, Podchorażych St. 2, PL 30-084 Kraków, POLAND

\begin{abstract}
In the examined part of central Poland, there are numerous kettle-hole basins filled with mineral and biogenic sediments of the Eemian Interglacial and Early Weichselian. These basins are located in varied geological and geomorphological locations with variable thicknesses of the sediments and deposits. The infillings were investigated by lithological and palaeobotanic methods. Lithology of the biogenic sediments is diverse, primarily gyttja and peat, but also organic silt. A number of the documented sites contain a record of environmental changes throughout the glacial-interglacial cycle from the end of the Warta Stadial (Saalian) to Early Weichselian. Local geological, geomorphological and hydrological conditions influenced the possibility of continuous peat-lake accumulation and the timing of the completion of this accumulation. Biogenic sediments are covered with the Middle and Late Weichselian mineral sediments which indicate climatic changes and are the main reason for rapid and synchronic degradation of kettle-hole infillings.
\end{abstract}

Keywords: biogenic deposits, closed depression, watershed, morainic upland, Eemian Interglacial, Early Weichselian (Vistulian), Poland

*Corresponding author (e-mail: jacek.forysiak@geo.uni.lodz.pl)

Editorial handling: Pertti Sarala (pertti.sarala@gtk.fi) 


\section{Introduction}

Small, closed depressions are characteristic features of morainic uplands in the Odranian (Saalian) glaciated area in central Poland. In this area, there are numerous kettle-hole basins filled with mineral and biogenic sediments of the Eemian Interglacial and the Early Weichselian age (e.g. Klatkowa, 1990; Roman, 2016). These basins are located in varied geological and geomorphological locations (morainic uplands, flat morainic watersheds, denudational valleys and glaciofluvial terraces). Sediments in many sites record environmental transformations that occurred since the end of the Warta Stadial (Saalian), through continuous successions of the Eemian Interglacial and Early Weichselian. This area was subsequently under periglacial conditions during the last glacial stage (Dylik, 1956), which led to extensive transformations of the landscape, including existing kettle-hole basins. Occasionally, accumulation of biogenic sediments occurred in the kettle-hole basins also during the Late Weichselian and the Holocene (cf. Twardy et al., 2010; Majecka et al., 2016).

Selected sites contain kettle-hole basins that were developed in glacial formations of the Late Warta Stadial age and formed a lake district during the last interglacial. Previous geological survey in the north-eastern part of the Łódź Upland suggested that these basins are steep-slope and deep (to $16 \mathrm{~m}$ ) kettle-holes, e.g., in the Żabieniec mire (Twardy et al., 2010). The kettle-holes are filled with glacial and interstadial biogenic sediments, mineral sediments (mainly periglacial) and mineral-biogenic sediments of interim intervals. As displayed by past correlations of lithological sections (Klatkowa, 1990), a substrate of the infillings is composed either of glacial till or glaciofluvial sandy and gravelly series of the Warta Stadial. The kettle-hole sediments are underlain by silt with sand accumulated at the termination of the Warta Stadial; accumulation of biogenic sediments had begun in some of the kettle holes at the same time (Klatkowa, 1990). A lithology of the biogenic series is diverse: lake sediments, peat and silt, and the deposition ended in the Plenivistulian.
Small, closed depressions are usually a few meters deep today, but their buried bottoms are located much deeper. Their surface infilling is composed generally of mineral deposits accumulated in a cold climate of the Upper Plenivistulian (Late Pleniglacial: see Marks et al., in press). Occasionally biogenic accumulation in such depressions occurred also in the Holocene. However, infillings of these basins contain organic and mineral-organic series of the Eemian and Early Weichselian) ages. Such depressions were documented not only in the Polish Lowlands (Klatkowa, 1990; Kupryjanowicz, 2008; Rychel et al., 2014; Roman, 2016), but also in Belarus, Lithuania and Germany (Litt et al., 1996; Kisieliene, 1999; Savchenko \& Pavlovskaya, 1999; Kühl \& Litt, 2003; Šeirienė et al., 2014; Börner et al., 2017).

Field studies were conducted in the Łódź Upland in central Poland, several dozen kilometres to the south of the line of the Last Glacial Maximum ice sheet limit (Fig. 1). The study area is predominated by glacial deposits of the Warta Stadial of the Odranian Glaciation (cf. Klatkowa, 1990; Turkowska, 2006; Marks et al., 2016).

The objective of this study was to reconstruct landscape transformation in a watershed area of central Poland during the Eemian and Early Weichselian, based on lithological and palynological analysis of organic deposits inside the selected postSaalian kettle-holes.

\section{Study area}

Investigations were carried out at four sites in the Łódź Upland: Józefów, Rogów, Pieńki Bielańskie and Żabieniec. The latter (Źabieniec) has already been described earlier (Twardy et al., 2010; Majecka, 2014; Majecka et al., 2016) and serves here as a reference site. Geological and paleobotanical studies have been performed previously at Józefów, where four kettle holes filled with mineral and biogenic sediments were examined (Dylik, 1963, 1967; Klajnert, 1965; Sobolewska, 1966). These geomorphologic features were interpreted by Dylik 
(1963, 1967) as relics of fossil pingos. Recently, a new sediment core has been collected from one of these kettle holes. The Rogów site is located in the watershed area of the Mroga River to the west and the Rawka River in the southeast, composed of till and glaciofluvial sand with gravel. The Żabieniec site is located in the watershed area between the Mrożyca River in the west and the Mroga River in the east. It is composed of a melt-out basin with a number of smaller, oval kettle holes around a peatland basin of the Żabieniec mire in the centre. A fossil depression at southern Żabieniec with the Eemian and Early Weichselian deposits is located in the southern part of Żabieniec site. The Pieńki Bielańskie site is located to the north of the Żabieniec site and is separated from it by end moraines, accompanied by an extensive patch of glaciofluvial sediments and underlain by a till of the Warta Stadial.

\section{Materials and methods}

Field work was initiated in 2015 and involved manual and mechanical drillings at each site, accompanied by sampling of mineral and biogenic deposits. Sediment cores with intact structures were collected from organic formations by means of geoprobe sampling (Majecka et al., 2016). We focused mainly on the lithology of sediments and the geomorphology of kettle holes; pollen analysis determined appropriate ages for the infillings. We present selected profiles from the sites where biogenic sediments were documented. Results of palynological examinations carried out for the biogenic sediments from the section B at Józefów made in the 1960s are compared with the 2012-2014 results from the southern Żabieniec site (Ż.Pd. core; Majecka, 2014). Preliminary palynological examination of the JO-1 core confirmed the Eemian-Early Weichselian age. Local pollen assemblage zones identified at Józefów by Sobolewska (1966) were correlated with pollen

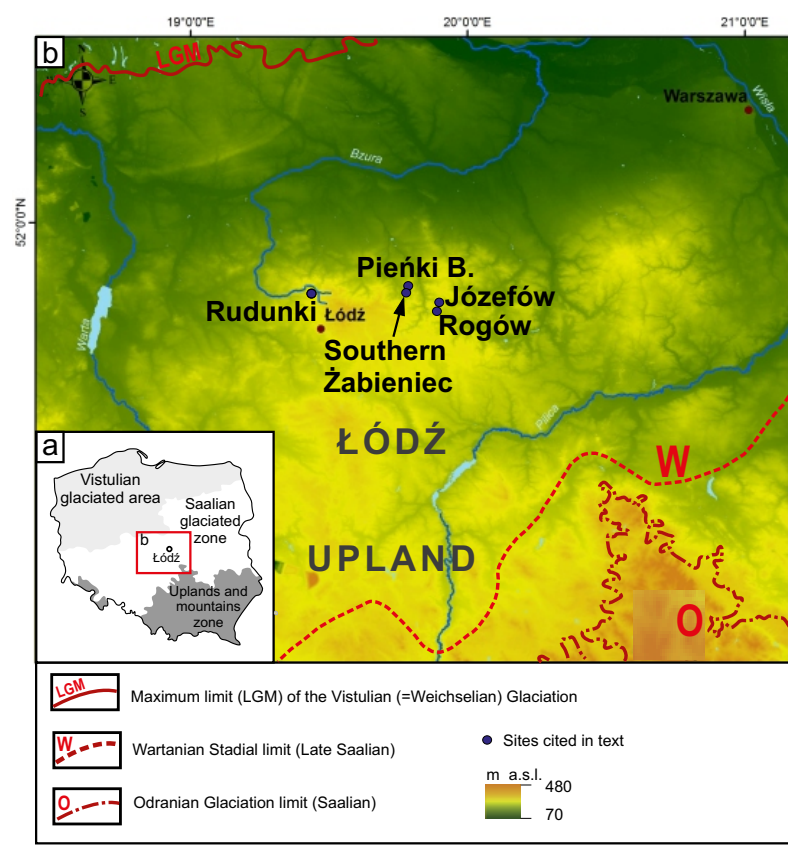

Figure 1. a) Location of the study sites in Poland. b) Location of the study sites in the northern part of the Łódź Upland in relation to the extents of the ice sheets.

phases of Jessen \& Milthers (1928). L PAZ from the southern Żabieniec (Majecka, 2014) were correlated with L PAZ at Józefów, and with regional pollen assemblage zones of Mamakowa (1989; Table 1).

From Józefów (JO-1 core) and southern Żabieniec (Ż.Pd. core) every second 3-cm or $5-\mathrm{cm}-$ thick sediment slice was collected for geochemical analyses. Sediment samples were dried at $105^{\circ} \mathrm{C}$ and homogenized. A relative content of organic matter was determined by the loss on ignition (LOI), with combustion at $550{ }^{\circ} \mathrm{C}$ for $4 \mathrm{~h}$, following the protocol described by (Heiri et al., 2001). Calcium carbonate $\left(\mathrm{CaCO}_{3}\right)$ content was estimated using the volumetric method with a use of the Scheibler apparatus (Woszczyk \& Szczepaniak, 2008). Upper layer of organic deposits from both cores was dated with radiocarbon conventional bulk-sediment method. Neither OSL method nor TL dating method was used in the research sites. 


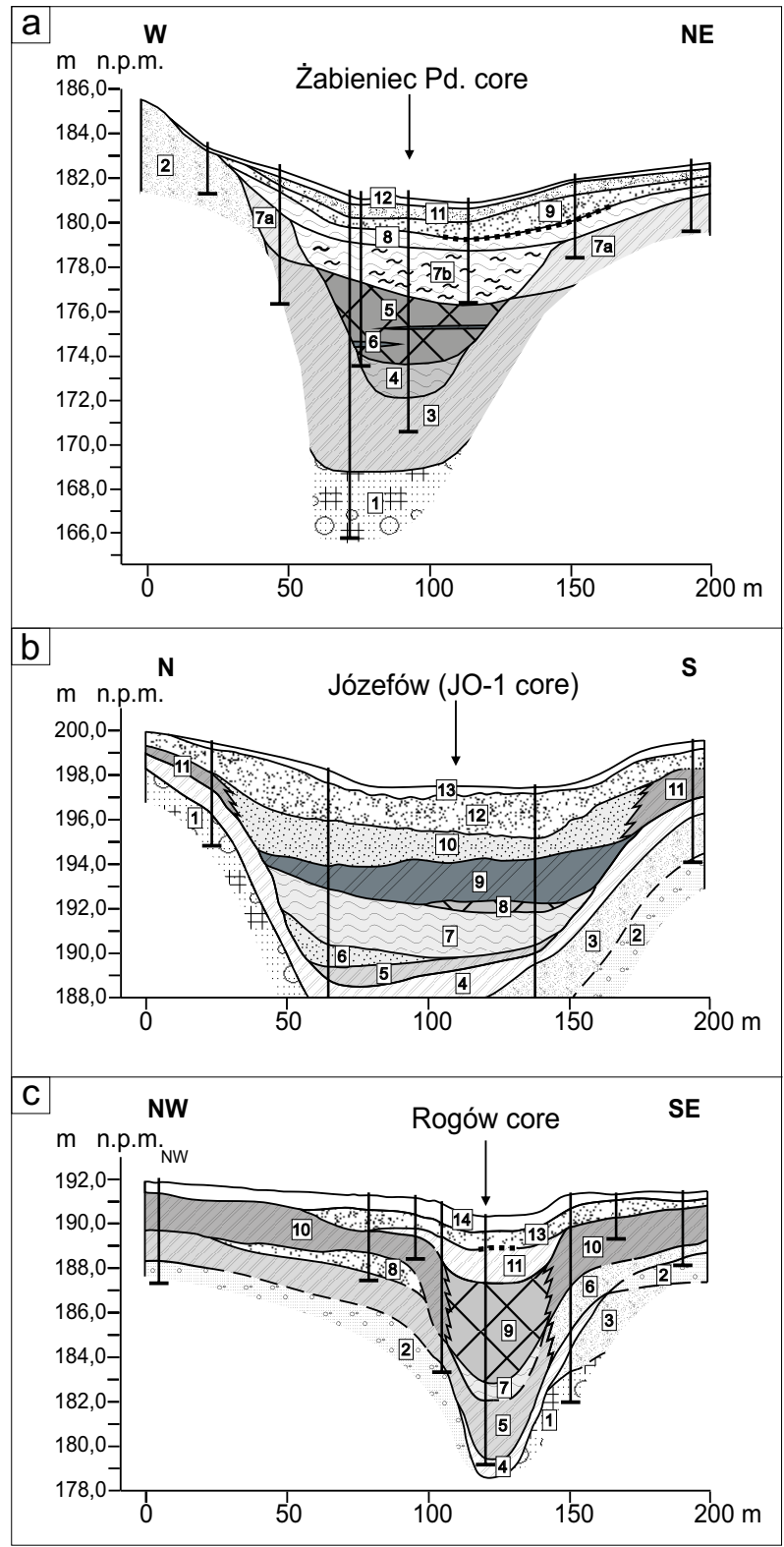

\section{Lithology, geochemical properties and palynological analysis}

A core $7.20 \mathrm{~m}$ long was collected from sediments of the kettle-hole infilling at Józefów C (JO-1). This core contained a continuous $5.3 \mathrm{~m}$-thick series of organic silt, gyttja and peat (Figs 2, 3). Lake deposits
Figure 2. a) Geological cross-section of the South Żabieniec depression; Warta Stadial: 1 - glacial till, 2 - glaciofluvial sand, 3 - mineral silt, 4 - mineralorganic silt; Eemian Interglacial and Early Vistulian: 5 - organic silt (with peat and gyttja), 6 - peat, $7 \mathrm{a}$ - deluvial silt and fine sand, $7 \mathrm{~b}$ - mineral-organic silt; Plenivistulian and Late Vistulian: 8 - mineral silt rebbeded with sand, 9 - vari-grained sand, 10 - cobble horizon, 11 - fine sand, 12 - recent soil with humus. b) Geological cross-section of the Józefów site (JO-1 core); Wartanian: 1 - glacial silty sand, 2 - glaciofluvial sand and gravel, 3 - glaciofluvial sand, 4 - sand with admixture silt, 5 - sand and mineralorganic silt, 6 - mineral-organic silt, 7 - fine sand; Eemian Interglacial and Early Vistulian: 8 - gyttja, 9 - peat; Plenivistulian and Late Vistulian: 10 - mineral silt with organic material, 11 - deluvial sand and silt, 12 - vari-grained sand with silt and gravel, 13 - recent soil with humus. c) Geological cross section of the Rogów site; Warta Stadial: 1 - glacial till, 2 - glacial sand and gravel, 3 - glaciofluvial sand, 4 - sand with silt, 5 - mineral silt, 6 - fine sand, 7 - mineral-organic silt, 8 - sand; Eemian Interglacial and Early Vistulian: 9 - gyttja and organic silt, 10 - deluvial silt and fine sand; Plenivistulian and Late Vistulian: 11 - mineral silt rebbeded with sand, 12 - vari-grained sand, 13 - recent soil horizon. and peat were documented at Rogów: these deposits are set on top of the Saalian till and covered with mineral periglacial formations (Fig. 2; Majecka et al., in press). Such sequence of biogenic deposits (total thickness of about $4.1 \mathrm{~m}$ ) were of EemianVistulian age on the basis of palynological analysis. A series of biogenic sediments was identified in a kettle-hole basin at Pieńki Bielańskie, composed of mineral-organic mud with gyttja interbeds and 


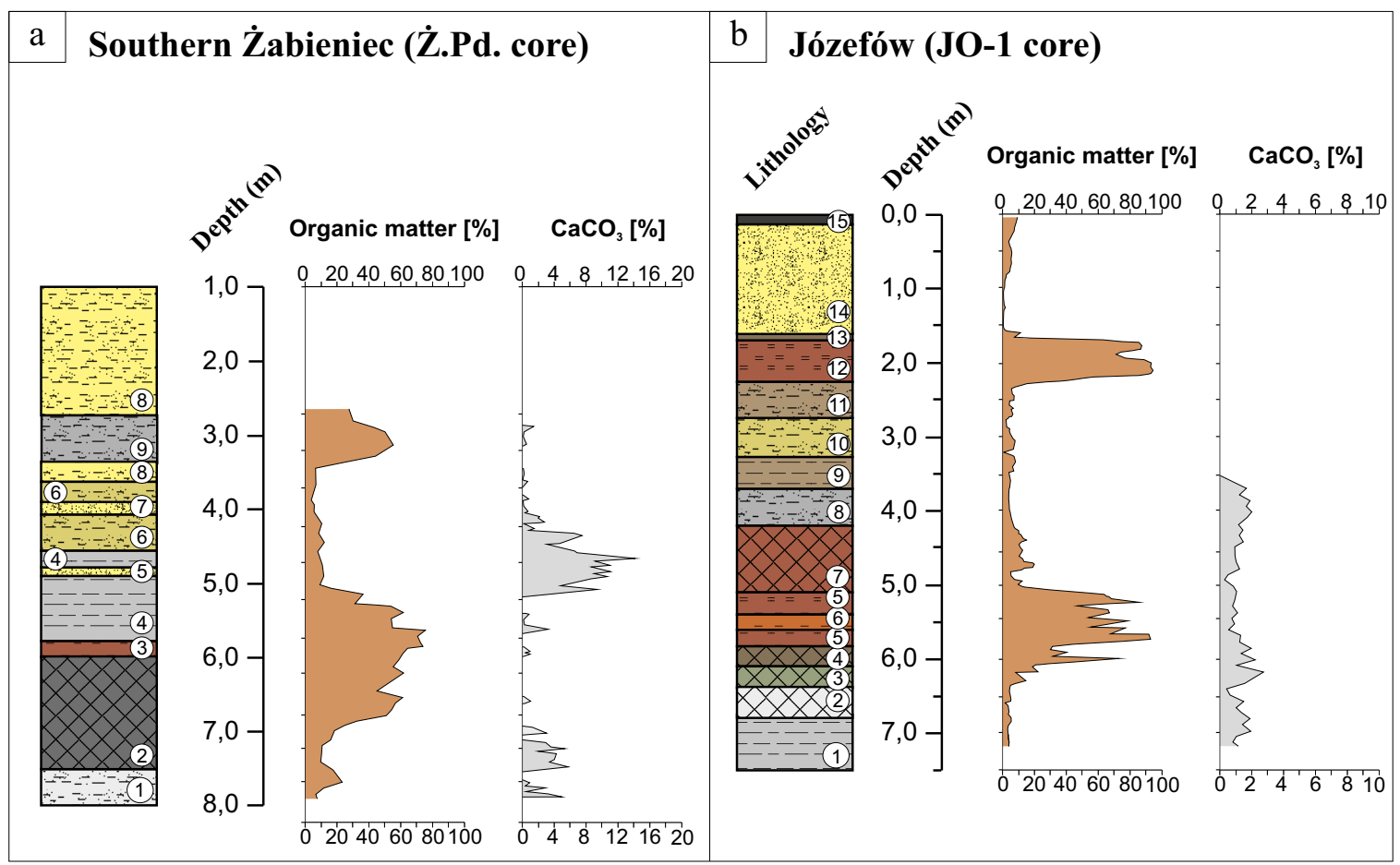

Figure 3. a) Lithology and content of the organic matter (LOI) and calcium carbonate $\left(\mathrm{CaCO}_{3}\right)$ of the southern Żabeniec site (Ż.Pd. core): 1 - mineral-organic silt, 2 - lake silt at the border of gyttja, dark grey, 3 - compact peat with wood detritus, 4 - silt with fine detritus, dark grey, 5 - varigrained sand, 6 - silt without detritus and with an admixture sand, 7 - mid-grained sand, 8 - fine-grained sand, 9 - organic silt, black. b) Lithology and content of the organic matter ( $\mathrm{LOI}$ ) and calcium carbonate $\left(\mathrm{CaCO}_{3}\right)$ of the Józefów site (JO-1 core): 1 - fine silt, gray, 2 - finedetrital-clay gyttja with mineral matter, 3 - algal gyttja with mineral matter, 4 - fine-detrital gyttja, black-brown, 5 - well decomposed peat, brown with plant fragments, 6 - moss peat, brown with plant fragments, 7 - fine-detritalclay gyttja with sand inserts, 8 - mineral-organic silt, grey, 9 - mineral-organic silt, brown, 10 - sand with silt and an admixture of organic matter, 11 - organic silt with disturbed sand, 12 - well decomposed peat, brown, 13 - organic silt, brown, 14 - fine-grained sand, yellow-gray, 15 - soil horizon with humus.

peat at the top (total thickness $1.75 \mathrm{~m}$ ). Organic sediments are covered with sand and sandy silt, and were preliminarily ascribed to the Eemian and Early Weichselian (Majecka et al., in press). A few basins with biogenic sediments were documented at the reference site Żabieniec. A core $10.8 \mathrm{~m}$ thick was collected at Southern Żabieniec (Ż.Pd) (Figs 2, 3) and it was analyzed for pollen. Biogenic sediments are underlain by a glacial till and comprise the interval since the termination of the Saalian to the Early Weichselian (Table 1).

So far, the best recognized sections come from southern Żabieniec (Ż.Pd) and Józefów (JO-1) sites. In both cases, similar organic matter content in lithological records indicates dominant role of allochtonic mineral deposition to the kettle-holes. High content of organic matter is connected with peat sedimentation, whereas minimal share of organic matter in the Early Weichselian is due to deposition of silt with admixture of sand.

A bottom part of the Ż.Pd core (depth 10.8$7.52 \mathrm{~m}$ ) is predominated by mineral silt and fine and coarse sand, with admixture of $\mathrm{CaCO}_{3}$ (Fig. 3) and less than $10 \%$ of organic matter. The overlaying sequence (depth 7.52-4.40 m) starts with lake silt, then passes into clayey gyttja, compacted peat, silt with fine detritus and terminates with sand. Such variability is indicated by an abrupt increase in LOI (from 8 to $74 \%$ ) and $\mathrm{CaCO}_{3}$ (from 0 to $18 \%$ ). These sediments are covered by vari-grained sands 
Table 1. Correlation of pollen assemblage zones from South Żabieniec and Józefów sites with regional biostratigraphy model.

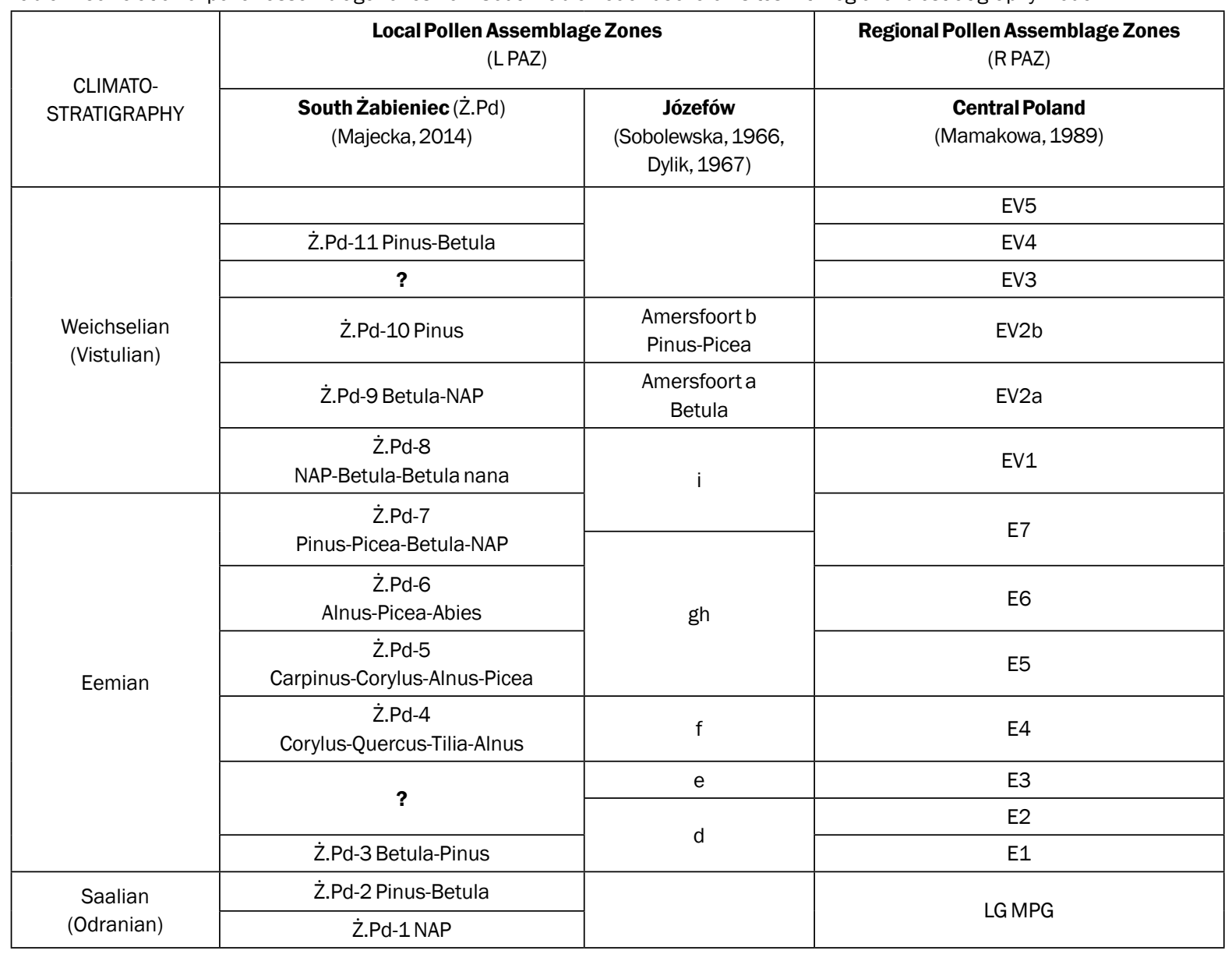

with admixture of silt and pieces of peat (depth $4.4-$ $0.0 \mathrm{~m}$ ). There is $22 \%$ of organic matter content in these sediments, although it is $>50 \%$ at $3.2-2.8 \mathrm{~m}$ depth. This upper layer of organic deposits was subjected to radiocarbon dating, but the result of dating (24 200 350 BP yrs (lab. no. LOD 1183)) is inconsistent with the results of palynological analysis (Majecka, 2014).

A bottom part of the JO-1 core (depth $7.2-6.6 \mathrm{~m}$ ) represents fine silt (organic matter $1.73-5.58 \%$ ), overlain at $6.6-5.9 \mathrm{~m}$ depth by fine-detrital gyttja (Fig. 3), compatible with an abrupt increase in LOI (from 5 to $73 \%$ ) and $\mathrm{CaCO}_{3}$ (from 0.6 to $2.7 \%$ ). At 5.9-5.0 m depth a medium decomposed peat with plant fragments was found. The average content of organic matter was $62 \%$, except for three layers (each about $2 \mathrm{~cm}$-thick) at $5.72,5.51$ and $5.26 \mathrm{~m}$ depths, rich in organic matter (above $80 \%$ ). A core at 5.0-2.2 m depth is represented by mineral-organic silt with admixture of sand, organic matter content from 0.03 to $19.9 \%$ and $\mathrm{CaCO}_{3}$ content $<1 \%$. At $2.2-$ $1.7 \mathrm{~m}$ depth, a decomposed peat occurred (LOI up to $94 \%$ ). Result of radiocarbon dating of peat from top of this layer is $23500 \pm 400 \mathrm{BP}$ yrs. (lab. No. MKL-3704), but it is incompatible with the pollen analysis made on sediments from Józefów. In the upper part of the core JO-1, there was finegrained sand with organic material (LOI decreased to $4.2 \%)$.

Eleven LPAZ were distinguished based on palynological analysis of the South Żabieniec core 
(Majecka, 2014; Table 1): two of the Warta Cold Period, five of the Eemian Interglacial (phases E1 to E7) and four of the Early Weichselian.

The kettle-hole section at Józefów was represented by gyttja, compressed and loose peat, and sandy gyttja, with a total thickness of $1.6 \mathrm{~m}$ (Sobolewska, 1966; Dylik, 1967). Biogenic sediments were underlain by till and clay with pebbles. Based on palynological analysis the bottom part of the biogenic sediments was correlated with the Eemian Interglacial, while the upper part was correlated with the Amersfoort Interstadial. Lithology of the biogenic sediments of the kettle-hole section Józefów B was slightly different from the one mentioned above. The peat, dated at the Eemian Interglacial according to Dylik (1967), was covered by clay, two beds of peaty silt and peat interlayered with gravel. According to Dylik (1967) and Zagwijn (1996), they correspond to the Amersfoort Interstadial.

\section{Interpretation and discussion}

In central Poland, approximately 60 sites with Eemian and Early Weichselian formations were recorded (Roman, 2016), some of them represented by deep and small kettle-holes at morainic uplands (Klatkowa, 1990). The present study was conducted in a part of the Łódź Upland, with a notably varied relief and kettle-holes located close to each other. The lake and peatland formation started in morphometrically similar kettle-holes at the end of the Warta Stadial or at the beginning of the Eemian Interglacial, depending on the size and depth of buried ice (Klatkowa, 1990). The termination of the biogenic deposition occurred mostly at the end of the Eemian or in the Early Weichselian, and occasionally also at the beginning of the Plenivistulian (Klatkowa, 1990; Roman, 2016). It was determined by local morphological and hydrogeological conditions, as well as induced by erosion that could incorporate non-drained basins into systems of denudation valleys, and often removed a part of the kettle-hole infillings (Klatkowa, 1990, 1996; Majecka, 2014).

Biogenic sediments at Józefów and Żabieniec were correlated with each other. As a consequence, it affected the stratigraphical positioning of the underlying and overlying mineral layers. These sites indicated diversified pollen-induced subdivision of the Eemian Interglacial, and an important distinction at the beginning of the Weichselian (Table 1). The stratigraphic setting of the pollen zone "i" at Józefów was repeatedly discussed by palynologists. It is located at the boundary of the Eemian Interglacial and Weichselian as distinguished by Andersen (1961) and Zagwijn (1961). Based on palynological premises of forest vegetation, Środon (1967) recognized the horizon "i” as the last stage of interglacial succession. It was moved to the first stage of the Early Weichselian succession at Imbramowice in southwestern Poland (Table 1), corresponding to R PAZ EV1 (Mamakowa, 1989).

A substrate of the kettle-hole and its catchment is composed of a till at Żabieniec and of glaciofluvial sand with gravel at Józefów. The kettle hole at Żabieniec is smaller and the lake accumulation seems to have been more stable during a warm period of the Eemian, but mineral matter and calcium carbonate contents were high during the colder phases of the Early Weichselian due to increased denudation of the surrounding slopes. At Józefów $\mathrm{C}$ the share of peat was higher and frequent changes in peat-gyttja accumulation occurred, presumably due to changing water conditions in the basin.

Gyttja of the Early Weichselian and the Eemian Interglacial at Józefów B is covered with sand and gravel (Dylik, 1967), and with a subsequent layer of peat and gyttja. The biogenic sediments underwent deformation during development and degradation of a pingo, initiated after the deposition of the "upper" peat (Early Weichselian), but before the Last Glacial Maximum, so most likely in the Lower Plenivistulian (Dylik, 1967). Highly compressed layers of peat and gyttja are known from previously examined sections (Sobolewska, 1966; Dylik, 1967) and found in the JO-1 core, thus possibly 
confirming the post-depositional impact on biogenic sediments.

Lake deposition at Southern Żabieniec started at the end of the Warta Stadial and terminated later than at Józefów. The sediments lack features of high compression, therefore, no post-depositional processes occurred at this site and the biogenic series of the Early Weichselian was capped with deluvial sand.

The most complete section of the examined period in the Łódź Upland was examined at Zgierz-Rudniki, where the site is located at the accumulation part of the denudation valley (Klatkowa, 1990). There are biogenic sediments at this site indicating the Eemian and two interstadials of the Early Weichselian (Jastrzębska-Mamełka, 1985), covered with mineral silt deposited in periglacial conditions. In northeastern Poland, a group of two melt-out kettle-holes was found, filled with biogenic sediments of the Eemian and the Early Weichselian (Rychel et al., 2014; Woronko et al., 2017). The original forms were remodelled at that site by subsequent intensive denudation, indicating more advanced periglacial climate during the Weichselian towards the northeast (cf. Marks et al., 2016, in press).

\section{Conclusions}

Biogenic sediments predominate infillings of many kettle-holes on morainic uplands in central Poland. Regardless of their geological and geomorphological location, their deposition is mainly limited to the Eemian Interglacial and the Early Weichselian.

\section{References}

Andersen, S.Th., 1961. Vegetation and its environment in Denmark in the Early Wieschelian Glacial (last Glacial). Danmark Geologiske Undersøgelse 2,61, 175 p.

Börner, A. Hrynowiecka, A., Stachowicz-Rybka R., Niska, M., Moskal-del Hoyo, M., Kuznetsov, V., Maksimov, F. \& Petrov, A., 2017. Palaeoecological investigations and ${ }^{230} \mathrm{Th} / \mathrm{U}$ dating of the Eemian Interglacial peat sequence from Neubrandenburg-Hinterste Mühle (Mecklenburg-
There are considerable lithological differences in the substrate of the biogenic deposits, either glacial or mineral lacustrine ones. The lithology of the biogenic sediments is also diverse, primarily gyttja and peat, but also organic silt. Even in kettle-holes located in similar geomorphological conditions and in close proximity to one another, different sediments were deposited. It depended on the kettle-hole depth, lithology of the catchment and water supply. The thicknesses of the sediments of the Eemian interglacial and the Early Weichselian are also quite varied in the examined sections. Local geological, geomorphological and hydrological conditions influenced peat-gyttja deposition and its time of termination.

Climatic shifts in the Middle and Late Weichselian in central Europe were the main reason for rapid and synchronic degradation of kettle-hole infillings. But periglacial processes at several sites led to deformation of biogenic sediments. Therefore, the present results are an input to research on climate change during the last interglacial/glacial transition in central Europe.

\section{Acknowledgements}

Authors thanks Dr Tatiana Minayeva and the anonymous reviewer and the Editor for their valuable comments, which helped to significantly improve the content of the article. Research project was funded by the National Science Centre in Poland (DEC-2014/15/B/ST10/03809).

Western Pomerania, NE Germany). Quaternary International 467, 62-78.

https://doi.org/10.1016/j.quaint.2017.04.003

Dylik, J., 1956. Coup d'oeil sur la Pologne periglaciare. Biuletyn Peryglacjalny 4, 195-238.

Dylik, J., 1963. Traces of thermokarst in the Pleistocene sediments of Poland. Bulletin de la Société des Sciences et des Lettres de Łódź 14, 1-16. 
Dylik, J., 1967. Główne elementy paleogeografii młodszego plejstocenu Polski Środkowej. In:

Galon, R. \& Dylik, J. (eds.), Czwartorzęd Polski. Państwowe Wydawnictwo Naukowe, Warszawa, 311-352. (In Polish)

Heiri, O., Lotter, A.F. \& Lemecke, G., 2001. Loss on ignition as a method for estimating organic and carbonate content in sediments: reproducibility and comparability of results. Journal of Paleolimnology 25, 101-110. https://doi.org/10.1023/A:1008119611481

Jastrzębska-Mamełka, M., 1985. Interglacjał eemski i wczesny vistulian w Zgierzu-Rudunkach na Wyżynie Łódzkiej. Acta Geographica Lodziensia 53, 1-75. (In Polish)

Jessen, K. \& Milthers, V., 1928. Stratigraphical and paleontological studies of interglacial deposits in Jutland and Northwest Germany. Danmarks Geologiske Undersøgelse II 48, 1-379.

Kisielienè, D., 1999. Floristic complexes from lacustrine sediments of Merkine Interglacial and Early Nemunas Glacial in the borehole Medininkai-117. Geologija 29, 50-56. (In Lithuanian)

Klajnert, Z., 1965. Budowa geologiczna i geneza zagłębień bezodpływowych w Józefowie. Przegląd Geograficzny 37, 143-162. (In Polish)

Klatkowa, H., 1990. Występowanie eemskich osadów organicznych i uwagi o paleomorfologii środkowej Polski u schyłku warty i podczas eemu. Acta Geographica Lodziensia 61,7-18. (In Polish)

Klatkowa, H., 1996. Symptoms of the permafrost presence in Middle Poland. Landform Analysis 2, 19-35.

Kupryjanowicz, M., 2008. Vegetation and climate of the Eemian and Early Vistulian lakeland in northern Podlasie. Acta Palaeobotanica 48, 3-130.

Kühl, N. \& Litt, T., 2003. Quantitative time series reconstruction of Eemian temperature at three European sites using pollen data. Vegetation History and Archaeobotany 12, 205-214. https://doi.org/10.1007/s00334-003-0019-2

Litt, T., Junge, F.W. \& Böttger, T., 1996. Climate during the Eemian in north-central Europe - a critical review of the palaeobotanical and stable isotope data from central Germany. Vegetation History and Archaeobotany 5, 247-256. https://doi.org/10.1007/bf00217502

Majecka, A., 2014. The palynological record of the Eemian Interglacial and Early Vistulian Glaciation in deposits of the Żabieniec Południowy fossil basin (Łódź Plateau, Central Poland), and its palaeogeographic significance. Acta Palaeobotanica 54, 279-302. https://doi.org/10.2478/acpa-2014-0007

Majecka, A., Balwierz, Z., Forysiak, J. \& Twardy, J., 2016. Eemian and Vistulian (Weichselian) development of the meltout depression on the watershed between the Mroga and Mrożyca Rivers (Central Poland) based on lithological and pollen analysis. Quaternary International 467,79-95.

https://doi.org/10.1016/j.quaint.2016.08.012
Majecka, A., Forysiak, J., Marks, L. \& Tołoczko-Pasek, A., in press. Lithological diversity of the deposits of closed depressions in Central Poland as a result of their origin conditions. Quaternary International, in press. https://doi.org/10.1016/j.quaint.2018.02.018

Mamakowa, K., 1989. Late Middle Polish Glaciation, Eemian and Early Vistulian vegetation at Imbramowice near Wrocław and the pollen stratigraphy of this part of the Pleistocene in Poland. Acta Palaeobotanica 29, 11-176.

Marks, L., Gałązka, D. \& Woronko, B., 2016. Climate, environment and stratigraphy of the Pleistocene last glacial stage in Poland. Quaternary International 420, 259-271. https://doi.org/10.1016/j.quaint.2015.07.047

Marks, L., Makos, M., Szymanek, M., Woronko, B., Dzierżek, J. \& Majecka, A., in press. Late Pleistocene climate of Poland in the mid-European context. Quaternary International, in press. https://doi.org/10.1016/j.quaint.2018.01.024

Roman, M., 2016. Pojezierze eemskie: uwagi o genezie i zaniku jezior polodowcowych centralnej Polski. Acta Geographica Lodziensia 105, 11-25. (In Polish)

Rychel, J., Karasiewicz, T., M., Krześlak, I., Marks, L., Noryśkiewicz, B. \& Woronko, B., 2014. Paleogeography of the environment in north-eastern Poland recorded in an Eemian sedimentary basin, based on the example of the Jałówka site. Quaternary International 328-329, 60-73.

https://doi.org/10.1016/j.quaint.2013.09.018

Savchenko I. \& Pavlovskaya I., 1999. Muravian (Eemian) and Early Poozerian (Early Weichselian) sequence at Azarichi section (Eastern Belarus). Acta Palaeobot. Suppl., 2, 523527.

Šeiriené, V., Kühl, N. \& Kisielienè, D., 2014. Quantitative reconstruction of climate variability during the Eemian (Merkine) andWeichselian (Nemunas) in Lithuania. Quaternary Research 82, 229-235. https://doi.org/10.1016/j.yqres.2014.04.004

Sobolewska, M., 1966. Results of palaeobotanic researches of Eemian deposits from Józefów, Łódź Upland. Biuletyn Peryglacjalny 15, 303-312.

Środoń, A., 1967. Stratygrafia późnego plejstocenu Polski niżowej na podstawie paleobotanicznej. In: Galon R. \& Dylik J. (eds.), Czwartorzęd Polski. Państwowe Wydawnictwo Naukowe PWN, Warszawa. 61-71. (In Polish)

Turkowska, K., 2006. Geomorfologia regionu tódzkiego. University of Lodz Press, 237 p. (In Polish)

Twardy, J., Żurek, S. \& Forysiak, J. (eds), 2010. Torfowisko Żabieniec: warunki naturalne, rozwój i zapis zmian paleoekologicznych w jego osadach. Bogucki Wydawnictwo Naukowe, Poznań, 214 p. (In Polish)

Woronko, B., Rychel, J., Karasiewicz, T., Kupryjanowicz, M., Adamczyk, A., Fiłoc, M., Marks, L., Krzywicki, T. \& Pochocka-Szwarc, K., 2017. Post-Saalian transformation of dry valleys in Eastern Europe: an example from NE Poland. Quaternary International 467, 161-177. https://doi.org/10.1016/j.quaint.2016.09.054 
Woszczyk, M. \& Szczepaniak, M., 2008. Reevaluation of the Scheibler method and its usefulness in the analysis of carbonate content in lake sediments. In: BajkiewiczGrabowska, E. \& Borowiak, D. (eds.), Anthropogenic and natural transformations of lakes. Department of Limnology, University of Gdańsk, Polish Limnological Society 2, 223-226.
Zagwijn, W.H., 1961. Vegetation, climate and radiocarbon dating in the Late Pleistocene of the Netherlands. Part I: Eemian and Early Weichselian. Medededelingen Geologisch Stichting 14, 15-45.

Zagwijn, W.H., 1996. An analysis of Eemian climate in Western and Central Europe. Quaternary Science Reviews 15, 451-469.

https://doi.org/10.1016/0277-3791(96)00011-X 